\title{
O POVOAMENTO E A MÚSICA RELIGIOSA EM MINAS GERAIS, NO SÉCULO XVIII.
}

Quando, em seu mundo mágico, o aborígene da terra brasileira viu, ou cuidou ver, a "itaverava-uçú" - a "Sabarabuçú", a Serra "que resprandece", na expressão do aventureiro castelhano Filipe Guilléu, em sua carta de 20 de julho de 1550 a El-Rei D. João III - o português, recém-chegado a São Paulo de Piratininga, acreditou no nativo da terra, porque vinha de outro mundo messiânico, igualmente cheio de prodígios, que era o tempo dos grandes descobrimentos marítimos. E, logo depois, também acreditou o espanhol, igualmente chegado ao planalto pela oportunidade da união dos dois Reinos, depois do grande Filipe. O castelhano acrescentava aos relatos míticos dos fura-matos ameríndios aquêle complemento. quixotesco do amor ao fabuloso que doma o sonho até fazê-lo realidade. E foi assim que o bandeirante - tipo racial nôvo, o "mameluco", que era a soma do índio, do português e do castelhano, sentiu-se impelido a ir procurar, nas profundezas dos "gerais sem tamanho". - como chama ao sertão o nosso Guimarães Rosa - a misteriosa montanha de prata ou esmeraldas: "acharia o que procurava", dizia um dêsses iluminados, "ou morreria na emprêsa".

Eis que a nostalgia da selva espicaça o bugre que reside dentro do mameluco a retornar à floresta primitiva donde partira e a ambição ibérico-semítica esporeia-lhe a vontade para se atirar à demanda do tesouro fabuloso. E êle parte para a aventura, deixando atrás os pagos pobres de Piratininga:

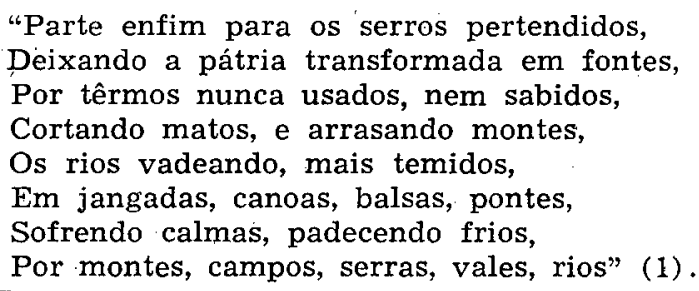

(1).. - Fragmento do poema, hoje desaparecido, de Diogo Garçāo Tinoco, poeta paulista de fins do século XVII. 
Esta oitava epopeica foi inspirada no feito bandeirante mais típico - a expedição de Fernão Dias Pais - e festeja o seu venerando herói. Apesar de já septuagenário, mas habituado às agruras da vida do sertão, Fernão Dias Pais toma aos filhos e parentes como seus lugares-tenentes e fazendo-se acompanhar de muitos paulistas, índios e tapanhunos, parte de São Paulo, em 1674, para o interior desconhecido à caça de esmeraldas. Não é preciso relembrar o esfôrço sobrehumano do velho bandeirante nessa comovedora expedição de tantos anos de trabalhos, sofrimentos, esperanças e desilusões, que acabaram por lhe consumir a vida. Em seus pousos forçados, Fernão Dias plantava roças para garantir a subsistência de sua bandeira. Ésses pousos foram a origem das primeiras povoações que surgiram nas futuras Minas Gerais: Ibituruna (a mais antiga), Santana do Paraopeba, O Sumidouro do Rio das Velhas, Roça Grande, Itacambira, Itamarandiba, Esmeraldas, Mato das Pedrarias e Serra Fria.

A expedição de Fernão Dias Pais, quanto às riquezas que pretendeu revelar, significou muito pouco. As ambicionadas esmeraldas, que procurou com tanto afã e que julgou ter achado, não passavam de simples turmalinas, de reduzido valor. Mas os efeitos da expedição foram maravilhosos, pois ela abriu aos outros bandeirantes o próprio coração da terra mineira, onde estavam escondidos tesouros incalculáveis, que os paulistas logo foram encontrar. Mas, as esmeraldas e a prata, tão ansiosamente pesquisadas, não se ofereceram. Foram o ouro e os diamantes que êles descobriram ou ajudaram a achar, pois na declaração ufanística do poeta Cláudio Manuel da Costa -

"apenas se achará rio, córrego ou serra que não devesse aos paulistas o descobrimento de suas faisqueiras, e êstes são os serviços com que se têm acreditado, além de muitos outros, os naturais da cidade de São Paulo" (2).

Lá pelas alturas de 1692 o bandeirante Antônio Rodrigues Arzão embrenhou-se pelos sertões da Casa da Casca e atinou com as primeiras areias auríferas de aluvião: encheu delas seus alforges e foi comunicar ao Governador ao Espírito Santo o seu achado. Outros paulistas se lhe seguem no bom sucesso, como Bartolomeu Bueno da Siqueira e seu cunhado Manuel Ortiz de Camargo, na Serra de Itaverava, e o genro de Ortiz, Manuel Garcia, que descobre o Gualacho do Sul e os ouros da Serra do Itatiaia, em 1696. Há o manifesto oficial do descobrimento

(2). - Fundamento Histórico, in obras Poéticas de cláudio Manuel da costa, Rto de Janeiro, H. Garnier, 1903, 2 vols., t. I, p. 175. 
do ouro às autoridades de El-Rei de Portugal e começa o roldão dos aventureiros na direção das Minas. Agora, não são apenas paulistas que sobem as montanhas do ouro. Começa a chegar gente de tôda parte. A corrida para as Minas não tem paralelo nas crônicas da história do Brasil. Mesmo na história das Américas, - o continente do "el dorado"- da incandescente imaginação ibérica - só os espetaculares avanços dos conquistadores de Potosi, no vice-reinado do Perú, em 1545, e dos pioneiros da América do Norte, primeiro acorrendo à Califórnia, em meados do século passado, e depois se desabalando para as solidões geladas do Alasca, já em nosso centésimo, podem ser a ela comparados. A arremetida setecentista que durará até 1760 mais ou menos, revestir-se-á daquelas mesmas características de loucura coletiva que marca tôdas as buscas de ouro, desde o lendário Jasão e seus cinqüenta argonautas.

"A sêde insaciável do ouro - conta o cronista do "rush" mineiro, Antonil, testemunha dêle nos primeiros anos da centúria de 1700 - estimulou a tanto a deixarem suas terras, e a meterem-se por caminhos tão ásperos, como são os das Minas, que dificultosamente se poderá dar conta do número das pessoas que atualmente lá estão. Cada ano vem nas frotas quantidade de Portuguêses e de estrangeiros, para passarem às Minas. Das cidades, vilas, recôncavos, e sertóes do Brasil, vão brancos, pardos e negros, e muitos indios de que os Paulistas se servem. A mistura é de tôda a condição de pessoas: homens e mulheres; moços e velhos; pobres e ricos; nobres e plebeus, seculares, clérigos e religiosos de diversos institutos, muitos dos quais năo têm no Brasil convento nem casa" (3). "A exuberante cópia do ouro destas Minas escreve, em sua linguagem barroca o memorialista Simáo Ferreira Machado, trinta anos depois, em seu rarissimo livro Triunfo Eucarístico - deu logo um estrondoso brado cujos ecos soaram nos mais distantes e recônditos seios de tôda a América; alteraram a muitos moradores do Brasil a cultura dos campos; fizeram outros vacilantes; a muitos nos cabedais inferiores, e outros oprimidos da necessidade fizeram sair a êste Zênite das riquezas; convidando uns com esperança de melhoras, a outros com princípio de prosperidade e porque os primeiros habitadores do trabalho do caminho passaram logo à felicidade da fortuna, quase ao mesmo tempo, ou com pouco intervalo, vendo, e habitando a terra, em breve tempo das cidades, e lugares marítimos "sobreveio incalculável multidão" (4).

(3). - Cultura e opulência do Brasil, São Paulo, Melhoramentos, 1923, p. 213.

(4). - In Revista do Arquivo Público Mineiro, Ano VI, fascs. 3.0 e 4.0, p. 994. 
E' O "rush", a corrida coletiva de tôda a gente para o ouro. A invasão de gente é tão brutal, que seu atropêlo escandaliza, impacienta até, os espectadores desinteressados da dramática aventura. Assim é que o Pe. Belchior de Pontes, taumaturgo jesuíta de São Paulo, esconjura os paulistas que partem para as Minas, profetizando-lhes as desgraças que sucederão no grande "levantamento" (a guerra dos Emboabas) que se vai dar (5).

"E' um periodo nôvo de história que se inaugura, escreve o historiador Pedro Calmon - não mais a guerra. ao índio, dos mamelucos ou a paciente lavoura, do Recôncavo; porém, à imitação do que ocorrera no Perú e no México, a invasão, o deslocamento maciço, a improvisação dos arraiais, a violência e o delírio da procura dos ribeirões auríferos, do esbulho dos incautos, do predomínio dos poderosos - através do vasto território já pequeno para tanto povo" (6).

Com efeito, a população cresce impressionantemente em poucos anos. Já em 1697, só nas minas do Caeté, há 4 mil forasteiros. Um amanuense do Guarda-mor Garcia Rodrigues Pais orça, em 1705, os "mineiros" em 50 mil! A vida modorrenta da Colônia transforma-se como por encanto. As atividades agrícolas, geralmente espalhadas pelo litoral, quase chegam ao colapso. A nova mentalidade "mineira" se sobrepõe à do trato da gleba e a produção dos engenhos de açúcar cai vertịcalmente: é que o braço escravo vai ser empregado mais fácil e rendosamente nas faisqueiras das montanhas centrais da terra e o preço alto pelo qual se the paga obriga os senhores. de engenho a vendê-lo quase inevitàvelmente. $\mathrm{E}$, no fim, senhores e escravos acabam igualando-se, ao lado dos outros forasteiros, nativos e de além-mar, na marcha para as minas, pejando as estradas, chegando do sul pelos caminhos recém-abertos e do norte pelas veredas terrestres do gado e pelo São Francisco.

Para essa gente, as Minas afiguram-se uma nova Canaã, mas em que os rios não são de leite e mel, mas correm gordos de lama, sedimento milenar do trabalho das águas sôbre as rochas folheadas da chamada "série de Minas", que acabam por arrastar para o fundo o pó pesado e fulvo do precioso metal:

(5). - Pe. Manuel da Fonseca, Vida do Venerável Pe. Belchior de Pontes, Sãa. Paulo, Melhoramentos, 1932, cap. XXXII.

(6). - História do Brasil, Rio de Janeiro, Livraria José Olímplo, 1959, 7 vols., t. III, p. 960 . 
os Páctolos lendários, rios de leito folheado de ouro, irão ser encontrados nos ásperos sertões brasileiros.

Nos primeiros anos do ciclo aurífero, distribuídas as "datas" para os que vão chegando, descobrindo e manifestando os ouros, a fortuna sorri dadivosamente a todos: os paulistas, os primeiros a chegar, vão tirando o fácil ouro de lavagem, empunhando as suas batéias e peneirando o cascalho dos ribeirões; ou então, trabalham com almocafres ou picaretas os filôes superficiais. E' a fase pioneira da mineração, que vai durar pouco tempo, porque êsse ouro de lavagem começa logo a escassear. Então, a lavra passa para as margens dos ribeirões - os "tabuleiros" - onde principia a labuta mais penosa: cava-se, às vêzes profundamente, no terreno sedimentar, até se achar o cascalho, rico de possibilidades. Mas, como que negaceando, o ouro vai agora rareando nas "catas" dos tabuleiros, obrigando os mineradores a grimpar perigosamente as encostas, fincando as unhas e os ferros nas "grupiaras", nas "catas altas"- das rochas em decomposição, que se vão transformando em verdadeiras barrocas, pelas grandes escavações que exigem. Mais espertos e dispondo de maior mãode-obra, os forasteiros europeus, já em 1707, introduzem o "desmonte hidráulico". Em lugar de abrir catas e conduzir para o rio o cascalho, despejam jorros dágua sôbre os montes de terra aurífera, cavando e "desmontando" a terra dentro da mesma água, de modo que sòmente o cascalho do ouro fica e é levado numa calha de pedra ou de madeira - a "canoa" ou "corredeira" - onde panos felpudos, couros de boi ou de cabrito, retêm os grãos pesados de ouro, que logo o meneio da batéia apura com facilidade.

Junto dos ribeirões auríferos ou dos caminhos que a êles levam, vão surgindo as povoações, os "arraias". Os mais primitivos provêm das "habitações e costumes dos primeiros aventureiros que abarracavam como os ciganos" (7) - escreve o historiador inglês Robert Southey. Para êsses rudes homens o arraial ainda não é o domicílio nem o lar. E' apenas uma demora, um pouso, onde ficarão o tempo apenas suficiente para juntar o seu ouro. Não há preocupação de bom gôsto e do confôrto domésticos. Por isso, os primeiros arraiais não passam de esquálidos arruados, com o seu caráter de provisoriedade e improvisação nas casas construídas.

(7). - História do Brasil, Río de Janetro, B. L. Garnier, 1862, 6 vols., t. V., p. 69 . 
E povoando os arraiais; a mesma gente, ávida e brutal. Essa gente forma uma sociedade aluvional, instável, em tudo semelhante ao aflúvio das areias do ouro, hoje aqui, amanhã sabe Deus aonde. Gente sem lei nem grei. Um dito da época asseverava que "todo aquêle que atravessava a Serra da Mantiqueira (divisa com as Minas) ali deixava pendurada ou sepultada a consciência". Era a pura verdade. Atualizava-se assim o antigo conceito de vida dos homens da éra dos grandes descobrimentos: Ultra equinoxium non est peccatum. Tôda aquela súcia, que chegava de além-mar e dos outros cantos do Brasil, vinha siderada pela ambição mais implacável. Não havia melhores nem piores: todos se igualavam no afã da fortuna rápida e fácil. Daí porque não recuavam diante de qualquer obstáculo, físico ou moral. A cobiça era o critério do seu procedimento. Os princípios éticos, que houvessem recebido na infância ou na adolescência, eram logo sopitados em seus corações, ao respirarem o clima de febre e loucura das Minas. Esses rudes catadores de ouro e de diamantes (os diamantes foram descobertos entre 1725 e 1730) não haviam deixado seus lares do Velho Mundo para irem às Minas rezar. Nos seus sujos fardéis não se encontravam o catecismo ou a lei. Todos os ruhs em busca de ouro resultam nessa bruta materialidade, como tão bem aparece nos quadros do romancista dos placers americanos, Brett Hart.

Mas, em tôdas as civilizações, há um freio mais ou menos eficaz das paixões humanas: a religião. Se, nas Minas Gerais, a sua ação não foi tão moderada como se propunha, por causas que agora não iremos recordar, nem por isso deixou de se fazer presente. Principalmente depois da criação do Bispado de Mariana, em 1745, quando já tinha sido iniciada a fixação dos aventureiros na terra. Após 1730, dá-se o fenômeno social da sedimentação urbana em Minas, enquanto que considerável população se radica nos campos, desfeitas as primeiras ilusões da riqueza fácil na mineração. Os arraiais mineiros serão daqueles. em todo o Brasil. que se afirmarão como núcleos citadinos inteiramente amadurecidos, inclusive com as suas diferenciações urbanas típicas. Assim também o reconhece o sociólogo Gilberto Freyre (8). Há, pois, o povoamento efetivo da região centro-sul do Brasil, que fica definitivamente conquistada com o aparecimento dos primeiros centros urbanos permanentes do interior brasileiro.

(8). - Sobrados e Mucambos, Rio de Janeiro, José Olímpio, 1951, 2a. ediçūo, 3 vols., t. I, p. 119. 
A produção do ouro e dos diamantes irá fomentar o intercâmbio comercial entre essas vilas sertanejas entre si e delas com as portas do litoral. O afortunado pôrto das Minas Gerais, o Rio de Janeiro, se engrandecerá desde logo e não tardará a tornar-se Capital da Colônia, em 1763. Com o advento da civilização citadina, os costumes da Capitania das Minas Gerais evoluirāo extraordinàriamente, principalmente nas vilas mais importantes, cabeças de Comarcas, e no rico Arraial do Tijuco (hoje Diamantina), pátria dos diamantes. Como nunca, a civilizada Europa parece aproximar-se da rústica terra do ouro. Os homens se refinam, na aparência e nas vestes: penteiam e trançam os cabelos em forma de rabicho, atando-os com fitas de sêda ou de gorgorão e cobrindo-os com chapéu à Frederico, de três pancadas; vestem camisa de folhos com colarinho baixo, rematada por gravata de lenço branco bordado; colete de cetim de Macau, todo filado com lantejoulas, comprido à moda dos fraques, com botões de pedras; casaca de veludo de côres fortes e variadas, degolada, comprida, sem enflanque, com portinholas e canhões largos e dobrados; calção amplo de sêda ou veludo, guarnecido de fivelas de ouro sôbre as meias de sêda-pérola; calçam sapatoś rasos, pretos e despontados com fivelas cravejadas de gemas preciosas; firmam-se em bengala forte, de castão e ponteira de ouro, aquêle geralmente trabalhado; trazem sempre relógio, prêso a grossa cadeia de ouro ou cornalina; e, complemento de nobre distinção, ostentam à ilharga gracioso florete, de bainha de ouro e guarnição com forma de "S", que os menos importantes substituem pela "faca aparelhada", à cintura, com bainha e guarnições de prata. Como as mulheres ainda continuam muçulmanamente jungidas ao lar e apenas freqüentam as igrejas, é nas reuniões de família e nas cerimônias do culto que pompeiam seus luxos e elegâncias. Nesses momentos solenes, trazem na cabeça uma coifa de sêda branca prêsa aos cabelos com alfinetes, com borlas de ouro nas extremidades; os cabelos, empoados com polvilho de trigo ou mandioca ou frisados com fina banha de porco, exibem caprichosos anéis, com cachos pendentes; vestem camisa de folhos apertada ao pescoço, e espartilho de barbatanas, em que assentam um "macaquinho" de veludo com artísticas abotoaduras e flôres de pedra sôbre o busto; grossa gargantilha e pesados brincos de gemas encastodas; saia de muita roda com cauda, que arrepanham no braço, ao andar; sapatinhos de bico fino, levemente erguida a ponta, com salto de madeira à Luís XV; à mão, trazem elegante e esguio bas- 
tão, mas os dedos desaparecem sob a carga de numerosos anéis de ouro. $\mathrm{Na}$ intimidade doméstica, entretanto, elas usam um timão leve e folgado, apertado à frente e apanhado por uma cinta de sêda com borlas pendentes (9).

Esse quadro de requinte e bom gôsto retrata principalmente a sociedade do Arraial do Tijuco, na éra dos Contratadores dos diamantes e da famigerada Chica da Silva que, ainda décadas mais tarde, o viajante inglês John Mawe irá classificar como a côrte mais seleta e agradável do Brasil (10). Então como narra, com certa nostalgia, o historiador Joaquim Felício dos Santos, cronista da grandeza e decadência do Arraial do Tijuco -

"não era como no tempo de agora, em que as velhas ao som dos instrumentos vão em um canto tomar a posição de quadros de sala, e os velhos jogar a bisca, e quando muito o voltarete. Todos dançavam, não essas contradanças modernas, compassadas, monótonas, lentas, sem significação: era o minueto engraçado e expressivo, com lânguidos e voluptuosos requebros; contradanças ardentes e animadas; valsas figuradas, onde cada figura parecia significar um sentimento, um desêjo, um pedido; o doudejante fandango, regulado e aquecido pelo som vibrante de um xique-xique de prata. O tempo assim corria, as horas passavam, e o sol, muitas vêzes surpreendia as dançantes fatigados, mas não saciados" (11).

Mas, a música não vai representar, nessa nova sociedade americana, apenas êsse papel de animadora de salões mundanos ou de confidente de jovens apaixonados. Se ela exerceu, em todos os tempos, o seu papel de intérprete dos sentimentos humanos, no século XVI, principalmente depois que Pier Luigi da Palestrina, junto da Côrte pontifícia, e o grande Tomás Luís de Vitória, junto dos monarcas espanhóis, haviam instaurado uma música sacra, pura, litúrgica e liturgicista. E' verdade que a música dramática já disputa francamente o terreno do gôsto geral com a música religiosa. Aliás, nas Minas Gerais, irá repetir-se o conflito existente na Europa ilustrada, que se

(9). - Joaquim Felício dos Santos, Memórias do Distrito Diamantino, Rio de Janeiro, Ed. O Cruzeiro, 1956, 3a. edição, pp. 105-106.

(10). - Viagens ao Interior do Brasil, Rio de Janeiro, Zélio Valverde, 1944, p. 222.

(11). - Op. cit., p. 107. Acreditamos, porém, que não havia valsas nos salões tijuquenses do século XVIII, porque mesmo na Europa essa dança, vinda da côrte dos Habsburgos, só ganhou voga depois da éra napoleônica. o que John Mawe viu em 18io, no Tijuco, foram contradanças inglesas. (Op. cit., p. 248). 
traduzirá pelo aparecimento de uma plêiade de compositores da terra, artistas originais e atrevidos, que enveredarão, com grande desgôsto das autoridades eclesiásticas, pelos caminhos de uma música religiosa antes dramática do que litúrgica, motivo pelo qual o bispo D. Frei Antônio de Guadalupe achará nela "muita profanidade e endecência tanto nas letras como na solfa", recomendando nas igrejas uma "solfa honesta e decente", que deve ser cantado "por clérigos a contochão" (12). E' que, como na Europa, essa nova música barroca mineira começava a pôr de lado o côro puro e simples, para o realce do solo vocale e dos instrumentos; entrava-se no reinado do solo vocal e da orquestra e se descobria que, em lugar do côro a quatro ou oito vozes, a voz sòzinha tinha também poder de emoção e de expressão. Além do órgão, há também o violino, o óboe, a flauta, o cravo, até a trompa, e êsses instrumentos começam a participar das partituras musicais que se apresentam nas igrejas mineiras, em Vila Rica, no Tijuco, em São João-del-Rei .

A vinculação artística dêsses compositores das Minas Gerais aos mestres italianos da época é evidente. Se Cláudio Monteverde introduzira a nova concepção da música antes religiosa do que sacra - que iria culminar com João Sebastião Bach, em sua "Missa em Si Menor" - a escola napolitana, que se lhe seguiu, acentuava essas novas tendências no caminho do prestígio melódico e instrumental. E' verdade que o excelente Scarlatti cuidou de não romper com o passado. Mas, seus discípulos, e entre êstes, seu filho Domênico, Jomelli e João Batista Pergolesi fizeram do efeito o ponto caracteristico da escola, tanto veneziana como napolitana. Esta, então, fêz do efeito melódico o seu ponto de honra. Exemplo dessa constante é a "Salve Regina a duas vozes" de Pergolesi, em que o sentimento religioso vai cedendo à virtuosità do canto. A arte do canto está em ascensão e o cantor vai ganhando importância cada vez maior. Tornam-se figuras de lenda, em Nápoles, os castrati Baldassare Feri, o Farinelli, Francesco Antonio Pistocchi e Antonio Bernacchi. Outro documento musical de Pergolesi, que, pelo seu excesso de progressões e repetições das mesmas figuras, se oferece ao vedetismo do bel canto, será o seu "Stabat Mater": o triunfo da ópera não estaria muito longe. 
Quem transplantou para Portugal e dali para as Minas Gerais a música napolitana parece ter sido Domênico Scarlatti, filho do grande mestre. Em 1714, o infante D. Antônio, irmão de D. João V, esteve em Roma e tornou-se discípulo de Scarlatti. Voltando a Lisboa, convenceu o irmão a convidá-lo para professor de sua sobrinha, a princesa real D. Maria Bárbara de Bragança, especialmente dotada de gôsto musical. Em 1721, Scarlatti instalava-se na côrte do Magnânimo, como mestre da Capela Real, e ensinou a infanta até 1729 , quando esta saiu de Lisboa, para Madrí, a fim de casar-se com o príncipe das Astúrias, que foi o Rei D. Fernando VI. Quando em Lisboa, Domênico Scarlatti produziu bastante e a fama de sua presença e de sua escola deveria ter atravessado o Atlântico, com discípulos seus, que também se aventuraram aos ouros generosos que se lhes ofereciam, no El-dorado portentoso das Minas Gerais.

O fato é que, já em 1747 , o bispo do Rio de Janeiro, D. Antônio do Destêrro, em visita pastoral às Minas, profliga a próspera música que encontra nas igrejas de Vila Rica, "contrapondo sensualista de compositores sem escola, que não se podião numerar". Tão numerosos deveriam ser êsses! Não se podiam numerar, porque eram tantos e todos uns mulatos sem eira nem beira, muitos ainda escravos e alguns outros que iam nascendo forros. A música era o lenitivo do exílio e a inclinação atávica da raça atraía irresistivelmente para ela.

"Aquêles mulatos que se nâo fazem absolutamente ociosos - fala uma velha autoridade colonial (13) - se empregam no exercício de Músicas, os quais são tantos na Capitania de Minas que certamente excedeu o número dos que há em todo o Reino". E conclui, perguntando com a sua surdez irremediável: "Mas em que interessa ao Estado esta aluvião de Músicos?"

As aluviões passaram e fluiram, nas águas e nos tempos. $\mathrm{E}$ estariam ainda perdidas, não fôsse o trabalho paciente, sistemático, competente, de um ilustre pesquisador europeu, Kurt Lange que, há mais de vinte anos, começou a procurar, em Minas Gerais, o velho filão musical setecentista, que às vêzes aflorava em tradições musicais, em igrejas e festas familiares. Se a capitania mediterrânea florescera intensamente nas letras e nas artes do século, como não ostentar à frente da música, delas a mais bela, nomes que fôssem tão grandes como

43). - Desembargador José João Teixeira Coelho, Instrução para o Govêrno da Capitania de Minas Gerais; in R. A: P. M., ano VIII, fases. I e II, p. 562. 
os poetas Cláudio Manuel da Costa, Tomás Antônio Gonzaga, Alvarenga Peixoto, Silva Alvarenga, ou os escultores, arquitetos e pintores Antônio Francisco Lisboa, Arouca, Pereira dos Santos, Servas, Costa Ataíde? Era insistir na pesquisa e os resultados logo surgiriam. Descobrindo nas velhas casas mineiras antigos manuscritos musicais, pôde Kurt Lange reconstituir tôda uma série de obras de música religiosa do século XVIII, obras essas assinadas por êsses mulatos geniais, que se chamaram José Joaquim Emérico Lôbo de Mesquita, Inácio Parreira Neves, Marcos Coelho Neto e Francisco Gomes da Rocha (14).

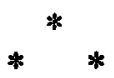

O primeiro dos mestres da música barroca mineira é José Joaquim Emérico Lôbo de Mesquita. Provàvelmente é originário do Arraial do Tijuco, a que já nos referimos. Surge por volta de 1782, como organista da Irmandade do Santíssimo Sacramento, da igreja de Santo Antônio, havendo entrado, em 1788, na Confraria de Nossa Senhora das Mercês dos Homens Pardos. Dez anos depois está em Vila Rica e, a partir de 1800, não fica dêle mais nenhuma notícia. Sua desenvoltura técnica faz.supor que tenha compôsto bastante. Esta "Antífona de Nossa Senhora", revela um autor de largos recursos, em dia com os mestres europeus do tempo, especialmente os sinfonistas italianos.

"Mais de uma vez - diz Kurt Lange - adianta-se mesmo a procedimentos dos seus contemporâneos do Velho Mundo, empregando frases desconcertantemente modernas, com um trabalho contrapontístico muito evoluido, e utilizando a sétima da dominante no início de um trecho - o que Beethoven faria pela primeira vez em 1800 , em sua "Sinfonia n. 1 ". Chama a atenção a liberdade com que utilizou as trompas, em sua "Missa em Mi Bemol". A obra de José Joaquim Emérico Lôbo de Mesquita pode figurar condignamente ao lado da dos grandes compositores europeus".

E' a conclusão de Kurt Lange.

(14). - Este trabalho resultou de uma conferência respectivamente pronunciada na Universidade de Madrí (Casa del Brasil) e no Pontifíclo Colégio de São Casemiro, de Roma, nos dias 27 de fevereiro e 5 de março dêste ano, pelo autor. 
O segundo mestre a ser apresentado, Inácio Parreira Neves, é natural de Vila Rica e desempenhou na antiga capital das Minas as funções de cantor, regente e compositor. Sua obra quase se perdeu inteira, tendo ficado apenas o "Credo", testemunho da admirável variedade de expressão, que emprega tão bem. O nome de Inácio Parreira Neves figura na relação dos cantores de Vila Rica desde 1756, quando deveria ser extremamente jovem. Por ocasião dos funerais de El-Rei D. Pedro III, em 1787, escreveu e dirigiu a música fúnebre, uma partitura para 4 côros, 4 rabecões, 2 fagotes e 2 cravos. $O$ autor do "Credo" morreu provàvelmente nos últimos anos do século XVIII.

O terceiro compositor é Marcos Coelho Neto, também de Vila Rica, cujo Hino "Maria Mater Gratiae" é um poema de ternura e devoção a Nossa Senhora, cheio de poderosa inspiração. Marcos Coelho Neto foi excelente trompista e tocou em diversas irmandades de seu tempo. Também foi regente e morreu em 1806 em sua terra natal.

$\mathrm{E}$, finalmente, o quarto maestro barroco setecentista de Minas Gerais, Francisco Gomes da Rocha, igualmente filho de Vila Rica, onde atuou como compositor e cantor. De suas obras, apenas chegou até nós a preciosa "Novena de Nossa Senhora do Pilar", de 1789, que o Professor Kurt Lange descobriu, e reconstituiu. 